\title{
Effect of hydroxyapatite particle size on myoblasts and fibroblasts
}

\author{
Jui-Sheng Sun*, Yang-Hwei Tsuang ${ }^{* \dagger}$, Walter Hong-Shong Chang ${ }^{\ddagger}$, \\ Jimmy Li $\mathrm{i}^{\ddagger}$, Hwa-Chang Liu* and Feng-Huei Lin ${ }^{\S}$ \\ ${ }^{\star}$ Department of Orthopedic Surgery, National Taiwan University Hospital, Taipei, Taiwan, ROC; 'Department of \\ Orthopedic Surgery, Taiwan Provincial Tao-Yuan General Hospital, Tao-Yuan, Taiwan, ROC; $\ddagger$ Institute of Biomedi- \\ cal Engineering, Chung-Yuan Christian University, Zhong-Li, Tao-Yuan, Taiwan, ROC; ' $\$$ Center for Biomedical \\ Engineering, College of Medicine, National Taiwan University, Taipei, Taiwan, ROC
}

\begin{abstract}
After surgery, the bone and soft tissues around integrated biomaterials can be adversely affected by implant-related factors acting over a period of years. However, few studies have directly addressed the effects upon the adjacent soft tissue. The present study was designed to test the biological effects of various sized hydroxyapatite (HA) particles on myoblasts and fibroblasts. Both the myoblasts and fibroblasts were mixed in in vitro culture with $0.1 \%\left(1 \mathrm{mg} \mathrm{ml}^{-1}\right)$ of various sized HA particles $(0.5-3.0$, $37-63,177-250,420-841 \mu \mathrm{m})$ for $1 \mathrm{~h}, 3 \mathrm{~h}, 1$ day, 3 days and 7 days to test their effects on the cell culture. The results show that adding HA particles into a cell culture can decrease the cell count significantly. The transforming growth factor- $\beta 1$ (TGF- $\beta 1$ ) concentrations in the culture medium decreased significantly on addition of HA particles. When calculated as a ratio to the cell number, the TGF- $\beta 1$ titre increased most significantly in the groups of medium-sized particles. The prostaglandin $E_{2}\left(P E_{2}\right)$ concentrations in the medium increased significantly. The changes in TGF- $\beta 1$ and PGE ${ }_{2}$ concentrations with the smallest particles were most significant and persisted longer. The inhibitory effects of the HA particles on the cell culture were mediated by the increased synthesis of $\mathrm{PGE}_{2}$. Caution should be exercised before considering the use of an HA product which could easily break down into a fine powder. (C) 1997 Elsevier Science Limited. All rights reserved
\end{abstract}

Keywords: Hydroxyapatite, particle size, myoblasts, fibroblasts

Received 15 June 1996; accepted 15 October 1996

Recent advances in orthopaedic surgery can be attributed to the revolution in biomaterials. During the last decade, a large number of biomaterials have been proposed as artificial bone fillers for repairing bone defects. The materials most widely used in clinical medicine have been hydroxyapatite (HA) ceramics $^{1,2}$. The inertness of biomaterials is relative: even materials considered inert in bulk form are capable of eliciting an inflammatory reaction in particulate form ${ }^{3}$. It has been reported that the use of porous HA blocks results in an unacceptably high failure rate in clinical applications ${ }^{4}$.

After surgery, osteo-integration is employed. However, the bone and soft tissues around the integrated biomaterials can be adversely affected by implant-related factors acting over a period of years ${ }^{5}$. The effects of implants on bony tissue have been investigated $^{6,7}$. However, few studies directly addressed the effects upon the adjacent soft tissue. By testing the cells that give rise to particular tissues rather than the tissue itself, the biological effects of biomaterials on the soft tissue can be elucidated.

Host tissue responses to these materials are generally assessed by morphological and histological examinations at the implant site to evaluate their biocompatibility $^{8}$. It is difficult to examine the in vivo

Correspondence to Dr F.-H. Lin. reaction of a specific cell to the substrate because numerous cell populations and chemical factors are involved in implantation. In order to determine the sequences of events and the parameters influencing the interactive process, a model of the cell culture in the presence of biomaterials is of great importance.

It has been recognized for a long time that particulate debris around an orthopaedic implant has an adverse effect on the surrounding tissues ${ }^{9}$. Initially, it was assumed that the damaging effect of the particles was essentially similar to that of the bulk material except that the particles have a larger surface area to interact with the surrounding tissues. More recently, it has been suggested that the adverse effects depend more on the particulate nature of the material than its chemical biocompatibility ${ }^{10}$. However, there is not yet any general understanding of the mechanisms by which particulate materials might exert a harmful effect greater than that of the parent material. Cytokines are polypeptide mediators which can be produced by a variely of cells. The cytokine networks can regulate cellular events and have distinct interactions with tissue. Through the production of cytokines the cells send out messages on a local or systemic level ${ }^{11}$. The present study was designed to test the mechanism of biological effects of various sized HA particles on myoblasts and fibroblasts. 


\section{MATERIALS AND METHODS}

\section{Material tested}

Hydroxyapatite (HA: $\mathrm{Ca}_{5}\left(\mathrm{PO}_{4}\right)_{6}(\mathrm{OH})_{6}$, Merck, Germany) powder was prepared as follows. The HA powders were placed in a platinum crucible and heated up to $1250^{\circ} \mathrm{C}$ at a heating rate of $3^{\circ} \mathrm{Cmin}^{-1}$ in a conventional $\mathrm{Ni}-\mathrm{Cr}$ coiled furnace and then maintained in air for $1 \mathrm{~h}$ after the sintering temperature of $1250^{\circ} \mathrm{C}$ was reached. The sintered particles were ground and separated with mesh into various grain sizes of about $0.5-3.0,37-63$, 177-250 and 420-841 $\mu \mathrm{m}$. HA particles were spherical in shape at various grain sizes according to scanning electron microscopic observation. Trace elements that might he connerted with biocompatibility were detected by atomic absorption analysis. The concentrations of the trace elements were much lower than the maximum tolerable level. Prior to use, they were processed by dry heat sterilization $\left(130^{\circ} \mathrm{C}, 40 \mathrm{~min}\right)$.

\section{Enzyme digestion of myoblasts and fibroblasts}

The method of enzymatic digestion of myogenic cells was similar to that of Bischoff, ${ }^{12}$ with some modification. Briefly, newborn Wistar rats of both sexes were anaesthetized with pentothal $(25 \mathrm{mg}$ per $100 \mathrm{~g}$, intraperitoneal injection). The rat was prepared and disinfected. The skeletal muscles of the hind limbs were excised and rinsed several times with sterile normal saline solution. Muscle tissue was then minced into $1-\mathrm{mm}$ fragments. The tissue fragments were trypsinized twice at $37^{\circ} \mathrm{C}$ for $30 \mathrm{~min}$ with $0.25 \%$ trypsin (Gibco, UK). After each digestion, the fragments were removed by low speed centrifugation $(500 \mathrm{~g}$ for $1 \mathrm{~min}$ ) and transferred to fresh medium for further dissociation. The supernatant containing the liberated cells was centrifuged again ( $1500 \mathrm{~g}$ for $3 \mathrm{~min}$ ) to pellet the cells and large debris while leaving most of the myofibrils in suspension. The pellet was suspended in fresh medium and aliquots were transferred to culture dishes. Enrichment of the myoblast population was accomplished by pre-plating the cells at $37^{\circ} \mathrm{C}$ for $30 \mathrm{~min}$ on a non-coated dish. The cells pre-plated at the bottom of the dish are mainly fibroblasts. This study received prior approval of the National Taiwan University Medical College's Animal Research Committee.

\section{Experimental procedures}

In the experiment, confluent rat myoblast or fibroblast cultures were seeded into six $3.0 \times 3.0 \mathrm{~mm}^{2}$ tissue culture wells (seeding density of $1 \times 10^{5}$ cells per well). The culture medium used was Dulbecco's modified Eagle's medium (DMEM) supplemented with $10 \%$ fetal calf serum (Gibco, UK), $100{\text { units } \mathrm{ml}^{1}}^{1}$ penicillin $G$ sodium and $100 \mathrm{mg} \mathrm{ml}^{-1}$ streptomycin (Gibco, UK). The dishes were incubated at $37^{\circ} \mathrm{C}$ in an atmosphere supplemented with $5 \% \quad \mathrm{CO}_{2}$ for $24 \mathrm{~h}$ to facilitate the attachment of myoblasts and fibroblasts. The medium was then removed and washed twice with phosphate-buffered saline (PBS) solution. DMEM supplemented with ITS (insulin, $10 \mu \mathrm{g} \mathrm{ml}^{-1}$, transferrin, $5 \mu \mathrm{g} \mathrm{ml}^{-1}$ and sodium selenite, $5 \times 10^{-3} \mu \mathrm{g} \mathrm{ml}^{-1}$; Sigma Corp.) was mixed with $0.1 \%\left(1 \mathrm{mg} \mathrm{ml}^{-1}\right)$ of various sized HA particles. The day of plating was considered as the zero day of culture. The test media were removed from the wells after $1 \mathrm{~h}, 3 \mathrm{~h}$ and 1,3 and 7 days, divided into sections of $500 \mu$ l with Eppendorf, and deep frozen at $-80^{\circ} \mathrm{C}$ till further analysis.

\section{Cell count}

After removal of the medium, the wells were fixed with $3 \%$ formaldehyde in $0.1 \mathrm{M}$ PBS ( $\mathrm{pH} \mathrm{7.4).} \mathrm{The} \mathrm{samples}$ were stained with haematoxylin-eosin and then observed by inverted microscopy (Olympus, IMT-II, Japan). The cellularity of the control and experimental wells was determined by an MICD image analysing system (MICD Software Series, Image Kesearch Inc., Ontario, Canada). Briefly, the mean cell population in four randomly selected high-power fields $\left(0.06 \mathrm{~mm}^{2}\right)$ was measured by counting the number of nuclei caught by CCD-72 camera (Dage-Mill Inc., Michigan, USA) through the microscope. Then the cell count per well was calculated by multiplying by the area of each well $\left(940 \mathrm{~mm}^{2}\right.$ per well).

\section{Surface area}

For the measurement of the surface area of the cells, more than 100 cells were counted in randomly selected high-power fields for each well. After calibration with a standard, the mean surface area of the cells in each well can be automatically calculated by using the MICD image analysing system.

\section{Transforming growth factor- $\beta 1$ (TGF- $\beta 1$ ) in culture medium}

The production of TGF- $\beta 1$ in the culture medium was analysed by enzyme-linked immunosorbent assay (ELISA) methods. Briefly, $200 \mu \mathrm{l}$ of standard or sample were added per well. The tested samples were incubated for $3 \mathrm{~h}$ at room temperature on the benchtop. Then $200 \mu \mathrm{l}$ of TGF- $\beta 1$ (R \& D System, Inc., USA) conjugate were added. The mixture was incubated for $1.5 \mathrm{~h}$ at room temperature. Substrate solution $(200 \mu \mathrm{l})$ was then added to each well. The reaction was stopped and read with a Microelisa reader (Emax Science Corp., USA) at $450 \mathrm{~nm}$ after $20 \mathrm{~min}$ incubation.

\section{Prostaglandin $\mathrm{E}_{\mathbf{2}}\left(\mathrm{PGE}_{2}\right)$ in culture medium}

The production of prostaglandin $\mathrm{E}_{2}\left(\mathrm{PGE}_{2}\right)$ in the culture medium was also analysed by ELISA methods. Briefly, $50 \mu \mathrm{l}$ of standard $\mathrm{PGE}_{2}$ (Cayman Chemical Company, MI, USA) or sample were added per well. The tested samples were incubated for $18 \mathrm{~h}$ at room temperature on the benchtop. Then $200 \mu$ l of Ellman's reagent were added to each well and the mixtures incubated for $1.5 \mathrm{~h}$ at room temperature. The reaction was stopped and read with a Microelisa reader at $405 \mathrm{~nm}$.

\section{Statistical analysis}

The effects of various sized $\mathrm{HA}$ particles were evaluated by an analysis of variances (ANOVA) statistical method. The post hoc test performed was Bonferroni's test. The level of statistical significance is defined as $P<\mathbf{0 . 0 5}$. 


\section{RESULTS}

\section{Cell count}

Adding HA particles into a cell culture can significantly affect the cell count. The cell populations of the control and various sized HA particles are summarized in Table 1. The changes in cell population of various preparations at $1 \mathrm{~h}, 3 \mathrm{~h}, 1$ day, 3 days and 7 days were all statistically significant $(P<0.0001$ by the ANOVA test) (Table 1).

The cell population of the control increased persistently except at $3 \mathrm{~h}$ after passage of cells. When cultured with HA particles, the cell populations of all experimental groups were significantly lower than that of the control ( $P<0.05$ ) (Table 1). The changes in cell population were quite similar between the groups with HA of $37-63,177-250$ and $420-841 \mu \mathrm{m}$ and lower than that of control. The cell population of the smallest sized HA (0.5-3.0 $\mu \mathrm{m})$ was even lower than that of the control group and groups with other sized HA particles (Table 1). The cell population of the smallest sized HA has the fewest cell populations (Figure 1).

\section{Surface area}

The mean surface area of cells in various preparations is shown in Table 2. The mean surface area of myoblasts in the control group increased and then decreased on the first day and then increased gradually up to the 7 th day of culture (Table 2). The mean surface area of myoblasts in the groups cultured with larger sized HA particle (4t20-841 $\mu \mathrm{m})$ increased on the first day of culture, decreased till the 3rd day of culture, and then increased again till the 7 th day of culture (Table 2). The mean surface area of myoblasts in the smaller size (177-250, 37-63 and 0.5-3.0 $\mu \mathrm{m}$ ) increased in the first 3 days, then decreased gradually till the 7 th days' culture (Table 2). The differences in the mean surface areas of the myoblasts were always statistically significant between the control group and the various tested experimental groups.

The mean surface area of the fibroblasts in the control group decreased and then increased in the initial 3 days of culture, then decreased gradually till the 7 th day of culture (Table 2). The mean surface area of fibroblasts in the groups cultured with various sized HA particles (420-841, 177-250 and 36-63 $\mu \mathrm{m}$ ) increased on the first day of culture, and then increased again till the 7th day of culture (Table 2). The differences in mean surface area of the fibroblasts were always statistically significant between the control group and various tested experimental groups.

\section{Transforming growth factor- $\beta 1$ (TGF- $\beta 1$ ) in culture medium}

The transforming growth factor- $\beta 1$ (TGF- $\beta 1$ ) concentrations in the culture medium were significantly affected by the addition of HA particles, especially when the particles are smaller in size. The TGF- $\beta 1$ concentrations in culture medium of various preparations are shown in Table 3. The changes of TGF- $\beta 1$ concentration in medium at $1 \mathrm{~h}$ and $3 \mathrm{~h}$ were low and not statistically significant $(P>0.05)$. The changes of TGF- $\beta 1$ concentrations in the medium on 1 day, 3 days and 7 days were statistically significant $(P<0.05$ by ANOVA test) (Table $3)$. The TGF- $\beta 1$ concentration in culture medium of the smallest sized hydroxyapatite $(0.5-3.0 \mu \mathrm{m})$ was always significantly lower than that of the control medium 1 day after implantation (Table 3). The decreases of TGF$\beta 1$ concentration in the culture medium was most significant in the groups with the smallest particles.

When calculated as a ratio to the cell number, the TGF- $\beta 1$ titre of all particles sizes increased as the culture time increased. The increase in the TGF- $\beta 1$ titre were most significant in the groups of medium size (i.e. $37-63$ and $177-250 \mu \mathrm{m}$ ) particles (Figure 2).

\section{Prostaglandin $\mathrm{E}_{\mathbf{2}}\left(\mathrm{PGE}_{2}\right)$ in culture medium}

The concentrations of prostaglandin $\mathrm{E}_{2}\left(\mathrm{PGE}_{2}\right)$ in culture medium of various preparations are shown in Table 4. The changes of $\mathrm{PGE}_{2}$ concentration were statistically significant $(P<0.0001$ by ANOVA test). The concentrations of $\mathrm{PGE}_{2}$ in the experimental medium are always significantly higher than that of control medium (Table 4).

Table 1 The changes in cell population of cells cultured with various-sized synthetic hydroxyapatite (HA) particles at a concentration of $1 \mathrm{mg} \mathrm{ml}^{-1}(N=10)$

\begin{tabular}{|c|c|c|c|c|c|}
\hline \multirow[t]{2}{*}{ HA particle size $(\mu \mathrm{m})$} & \multicolumn{5}{|c|}{ Cell count $\left(\times 10^{4}\right.$ per well $)$} \\
\hline & $1 \mathrm{~h}$ & $3 \mathrm{~h}$ & 1 day & 3 days & 7 days \\
\hline $\begin{array}{l}\text { Myoblasts } \\
\text { A }(0.5-3.0) \\
\text { B }(37-63) \\
\text { C }(177-250) \\
\text { D }(420-841) \\
\text { E Control }\end{array}$ & $\begin{array}{l}3.01^{\star \star *} \text { (S.D. 0.94) } \\
5.45^{\star \star *} \text { (S.D. } 1.03 \text { ) } \\
5.55^{\star \star *} \text { (S.D. 0.85) } \\
5.92^{\star \star \star} \text { (S.D. 0.56) } \\
7.61 \text { (S.D. 1.13) }\end{array}$ & $\begin{array}{l}0.38^{* * *} \text { (S.D. 0.19) } \\
1.98^{\star} \text { (S.D. } 0.75 \text { ) } \\
1.98^{\star \star} \text { (S.D. } 0.75 \text { ) } \\
1.88^{\star *} \text { (S.D. } 0.85 \text { ) } \\
2.91 \text { (S.D. 1.32) }\end{array}$ & $\begin{array}{l}2.91^{\star \star *} \text { (S.D. 0.75) } \\
7.71^{\star \star} \text { (S.D. 1.13) } \\
7.89^{\star \star *} \text { (S.D. 1.32) } \\
8.65^{\star * *} \text { (S.D. 1.13) } \\
12.31 \text { (S.D. 1.79) }\end{array}$ & $\begin{array}{l}2.91^{\star \star} \text { (S.D. 4.89) } \\
4.89^{* *} \text { (S.D. 4.60) } \\
5.17^{\star} \text { (S.D. 6.54) } \\
5.17^{\star \star} \text { (S.D. 5.92) } \\
10.90 \text { (S.D. 5.63) }\end{array}$ & $\begin{array}{l}0.38^{* * *} \text { (S.D. 0.28) } \\
1.13^{* * *} \text { (S.D. 0.47) } \\
0.94^{* * *} \text { (S.D. 0.47) } \\
2.26^{* * *} \text { (S.D. 1.60) } \\
35.99 \text { (S.D. 7.24) }\end{array}$ \\
\hline$P$ value & $2.38 \times 10^{-12}$ & $1.46 \times 10^{-6}$ & $1.81 \times 10^{-14}$ & 0.024 & $7.19 \times 10^{-29}$ \\
\hline $\begin{array}{l}\text { Fibroblasts } \\
\text { A }(0.5-3.0) \\
\text { B }(37-63) \\
\text { C }(177-250) \\
\text { D }(420-841) \\
\text { E Control }\end{array}$ & $\begin{array}{l}3.76^{* * *} \text { (S.D. } 0.56 \text { ) } \\
4.60^{* * *} \text { (S.D. 0.66) } \\
4.89^{* * *} \text { (S.D. } 0.47 \text { ) } \\
5.45^{* *} \text { (S.D. } 0.94 \text { ) } \\
6.86 \text { (S.D. } 0.75 \text { ) }\end{array}$ & $\begin{array}{l}0.19^{* * *} \text { (S.D. } 0.09 \text { ) } \\
0.85^{\star * *} \text { (S.D. } 0.38 \text { ) } \\
1.32^{*} \text { (S.D. } 0.94 \text { ) } \\
1.22^{* *} \text { (S.D. } 0.94 \text { ) } \\
2.07 \text { (S.D. } 0.47 \text { ) }\end{array}$ & $\begin{array}{l}0.47^{\star \star *} \text { (S.D. 0.28) } \\
\left.3.20^{\star * *} \text { (S.D. } 0.56\right) \\
3.48^{\star \star *} \text { (S.D. 0.66) } \\
4.79^{\star *} \text { (S.D. 0.94) } \\
6.77 \text { (S.D. 1.69) }\end{array}$ & $\begin{array}{l}0.56^{\star \star *} \text { (S.D. 0.66) } \\
2.63^{\star \star *} \text { (S.D. 0.94) } \\
2.91^{\star \star *} \text { (S.D. } 1.22 \text { ) } \\
4.04^{\star \star *} \text { (S.D. } 1.79 \text { ) } \\
12.40 \text { (S.D. 1.79) }\end{array}$ & $\begin{array}{l}1.79^{\star \star \star} \text { (S.D. 1.13) } \\
3.95^{\star \star \star} \text { (S.D. 3.48) } \\
4.79^{\star \star *} \text { (S.D. 5.36) } \\
12.12^{\star \star *} \text { (S.D. 11.56) } \\
39.19 \text { (S.D. 11.18) }\end{array}$ \\
\hline$P$ value & $7.19 \times 10^{-12}$ & $6.77 \times 10^{-9}$ & $2.88 \times 10^{-17}$ & $7.66 \times 10^{-23}$ & $3.13 \times 10^{-14}$ \\
\hline
\end{tabular}

All data were analysed by the analysis of variance (ANOVA) test. S.D. = standard deviation.

${ }^{*} P<0.05 ;{ }^{*} P<0.005 ;{ }^{*{ }^{*} P}<0.0005$ when compared with control group. 


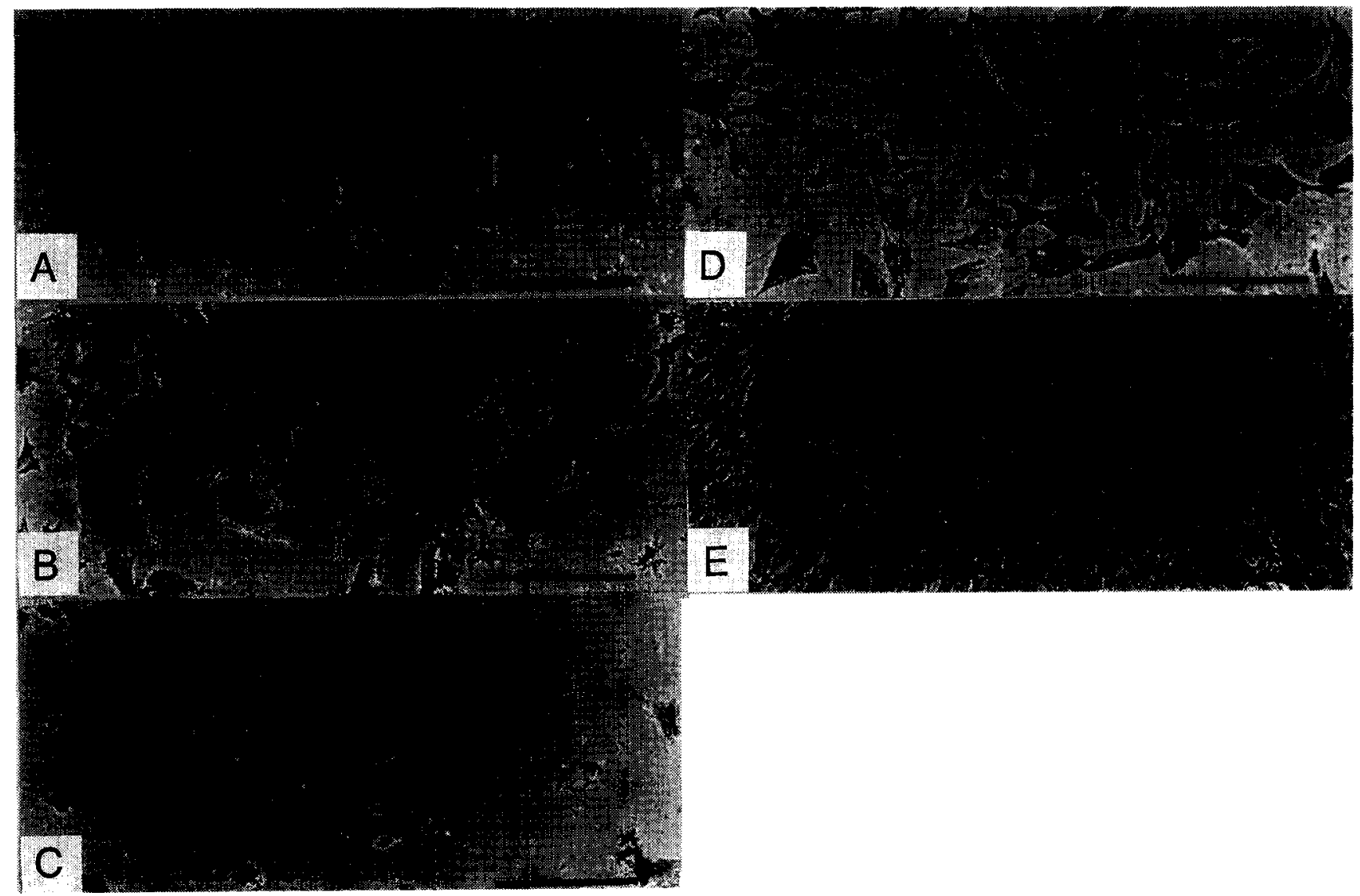

Figure 1 Representative photomicrographs of myoblast cell population after 7 days culture with various-sized hydroxyapatite (HA) bioceramics (A, 0.5-3.0 $\mu \mathrm{m}$; B, 37-63 $\mu \mathrm{m}$; C, 177-250 $\mu \mathrm{m}$; D, 420-841 $\mu \mathrm{m}$; E, control) (Bars, $100 \mu \mathrm{m}$ ). The addition of HA particles into the myoblast cell cultures can significantly affect the cell count. The changes in cell population were similar between the groups with HA of sizes $37-63,177-250$ and $420-841 \mu \mathrm{m}$ and lower than that of the control. The cell population of the smallest-sized HA particles $(0.5-3.0 \mu \mathrm{m})$ is the lowest.

The $\mathrm{PGE}_{2}$ concentration in the control medium of myoblasts increased in the first 3 days, then decreased gradually till the 7 th day. The $\mathrm{PGE}_{2}$ concentration in the control medium of fibroblasts increased on the first day, decreased gradually till the 3rd day, then increased gradually till the 7th day (Table 4). The changes of PGE concentration in culture medium tested with $\mathrm{HA}$ particles increased persistently till the 7th day. The

Table 2 The changes in mean surface area of the cells when cultured with various-sized synthetic hydroxyapatite (HA) particles at a concentration of $1 \mathrm{mg} \mathrm{ml}^{-1}(N=10)$

\begin{tabular}{|c|c|c|c|c|c|}
\hline \multirow[t]{2}{*}{ HA particle size $(\mu \mathrm{m})$} & \multicolumn{5}{|l|}{ Surface area $\left(\mu \mathrm{m}^{2}\right)$} \\
\hline & $1 \mathrm{~h}$ & $3 \mathrm{~h}$ & 1 day & 3 days & 7 days \\
\hline \multicolumn{6}{|l|}{ Myoblasts } \\
\hline$A(0.5-3.0)$ & $\begin{array}{l}1976.8 \\
\text { (S.D. 1181.5) }\end{array}$ & $\begin{array}{l}2031.2 \\
\text { (S.D. 996.9) }\end{array}$ & $\begin{array}{l}1505.3^{*} \\
\text { (S.D. } 818.9 \text { ) }\end{array}$ & $\begin{array}{l}3303.4^{* * *} \\
\text { (S.D. 1938.4) }\end{array}$ & $\begin{array}{l}3299.7^{\star * *} \\
\text { (S.D. 2187.9) }\end{array}$ \\
\hline$B(37-63)$ & $\begin{array}{l}2500.6^{\star \star \star} \\
\text { (S.D. } 1076.8 \text { ) }\end{array}$ & $\begin{array}{l}2617.1^{*} \\
(S . D .1334 .9)\end{array}$ & $\begin{array}{l}2484.9^{\star \star \star} \\
\text { (S.D. 1326.9) }\end{array}$ & $\begin{array}{l}2854.4^{* * *} \\
\text { (S.D. 2134.9) }\end{array}$ & $2457.2^{\star \star}$ (S.D. 1385.3) \\
\hline$C(177-250)$ & $\begin{array}{l}3068.5^{\star \star \star} \\
\text { (S.D. 1366.1) }\end{array}$ & $\begin{array}{l}2753.3^{* \star} \\
\text { (S.D. 1297.2) }\end{array}$ & $\begin{array}{l}2754.4^{\star \star \star} \\
\text { (S.D. 1332.6) }\end{array}$ & $\begin{array}{l}2951.4^{\star \star \star} \text { (S.D. } \\
2241.5)\end{array}$ & $\begin{array}{l}2179.3 \\
\text { (S.D. 1528.9) }\end{array}$ \\
\hline$D(420-841)$ & $\begin{array}{l}2626.9^{\star \star \star} \\
\text { (S.D. 1695.3) }\end{array}$ & $\begin{array}{l}2475.8 \\
\text { (S.D. 1172.2) }\end{array}$ & $\begin{array}{l}3125.5^{\star * \star} \\
\text { (S.D. 1688.8) }\end{array}$ & $\begin{array}{l}2319.5^{\star} \\
\text { (S.D. 1790.4) }\end{array}$ & $\begin{array}{l}3557.5^{\star * \star} \\
\text { (S.D. } 2420.3)\end{array}$ \\
\hline E Control & $\begin{array}{l}1815.1 \\
\text { (S.D. } 967.1)\end{array}$ & $\begin{array}{l}2264.6 \\
\text { (S.D. 1072.9) }\end{array}$ & $\begin{array}{l}1786.3 \\
\text { (S.D. } 954.3)\end{array}$ & $\begin{array}{l}1836.6 \\
\text { (S.D. } 917.9)\end{array}$ & $\begin{array}{l}1982.5 \\
\text { (S.D. 1361.1) }\end{array}$ \\
\hline$P$ value & $3.81 \times 10^{-12}$ & 0.0001 & $1.72 \times 10^{-7}$ & $1.72 \times 10^{-7}$ & $2.99 \times 10^{-11}$ \\
\hline \multicolumn{6}{|l|}{ Fibroblasts } \\
\hline $\begin{array}{l}\text { A }(0.5-3.0) \\
\text { B }(37-63) \\
C(177-250) \\
D(420-841) \\
\text { E Control }\end{array}$ & $\begin{array}{l}2654.4 \text { (S.D. 1425.5) } \\
4.60^{\star \star \star} \text { (S.D. 0.66) } \\
\left.4.89^{\star \star *} \text { (S.D. } 0.47\right) \\
\left.5.45^{\star *} \text { (S.D. } 0.94\right) \\
6.86 \text { (S.D. 0.75) }\end{array}$ & $\begin{array}{l}0.19^{\star * *} \text { (S.D. } 0.09 \text { ) } \\
0.85^{\star * *} \text { (S.D. } 0.38 \text { ) } \\
1.32^{\star} \text { (S.D. } 0.94 \text { ) } \\
1.22^{\star * *} \text { (S.D. } 0.94 \text { ) } \\
2.07 \text { (S.D. } 0.47 \text { ) }\end{array}$ & $\begin{array}{l}0.47^{* \star *} \text { (S.D. 0.28) } \\
3.20^{* * *} \text { (S.D. } 0.56 \text { ) } \\
3.48^{\star * *} \text { (S.D. 0.66) } \\
4.79^{\star \star} \text { (S.D. 0.94) } \\
6.77 \text { (S.D. 1.69) }\end{array}$ & $\begin{array}{l}0.56^{\star \star \star} \text { (S.D. 0.66) } \\
2.63^{\star \star *} \text { (S.D. 0.94) } \\
2.91^{\star \star *} \text { (S.D. 1.22) } \\
4.04^{\star \star \star} \text { (S.D. 1.79) } \\
12.40 \text { (S.D. 1.79) }\end{array}$ & $\begin{array}{l}1.79^{* * *} \text { (S.D. 1.13) } \\
3.95^{\star * *} \text { (S.D. 3.48) } \\
4.79^{* * *} \text { (S.D. } 5.36 \text { ) } \\
12.12^{* * *} \text { (S.D. 11.56) } \\
39.19 \text { (S.D. 11.18) }\end{array}$ \\
\hline$P$ value & $7.19 \times 10^{-12}$ & $6.77 \times 10^{-9}$ & $2.88 \times 10^{-17}$ & $7.66 \times 10^{-23}$ & $3.13 \times 10^{-14}$ \\
\hline
\end{tabular}

All data were analysed by the analysis of variance (ANOVA) test. S.D. = standard deviation.

${ }^{*} P<0.05 ;{ }^{* *} P<0.005 ;{ }^{* * *} P<0.0005$ when compared with control group. 
Table 3 The changes in transforming growth factor- $\beta 1$ (TGF- $\beta 1$ ) concentration in culture medium for cells cultured with various-sized synthetic hydroxyapatite (HA) particles at a concentration of $1 \mathrm{mg} \mathrm{ml}^{-1}(\mathrm{~N}=10)$

\begin{tabular}{|c|c|c|c|c|c|}
\hline \multirow[t]{2}{*}{ HA particle size $(\mu \mathrm{m})$} & \multicolumn{5}{|c|}{ TGF- $\beta 1$ concentration $\left(\mathrm{pg} \mathrm{ml} l^{-1}\right)$} \\
\hline & th & $3 h$ & 1 day & 3 days & 7 days \\
\hline $\begin{array}{l}\text { Myoblasts } \\
\text { A }(0.5-3.0) \\
\text { B }(37-63) \\
\text { C }(177-250) \\
\text { D }(420-841) \\
\text { E Control }\end{array}$ & $\begin{array}{l}1.8 \text { (S.D. 0.9) } \\
1.4 \text { (S.D. } 0.3 \text { ) } \\
1.3 \text { (S.D. } 0.2 \text { ) } \\
1.7 \text { (S.D. } 0.6 \text { ) } \\
1.2 \text { (S.D. } 0.4 \text { ) }\end{array}$ & $\begin{array}{l}3.2 \text { (S.D. 1.2) } \\
2.8 \text { (S.D. } 0.7 \text { ) } \\
2.8 \text { (S.D. } 0.9 \text { ) } \\
4.1 \text { (S.D. 1.8) } \\
2.7 \text { (S.D. 1.7) }\end{array}$ & $\begin{array}{l}9.9^{* \star} \text { (S.D. 3.3) } \\
20.8 \text { (S.D. 8.3) } \\
24.4 \text { (S.D. } 7.9 \text { ) } \\
21.9 \text { (S.D. 6.5) } \\
27.4 \text { (S.D. 6.6) }\end{array}$ & $\begin{array}{c}7.73^{\star \star \star} \text { (S.D. 12.3) } \\
119.4 \text { (S.D. 146.8) } \\
127.2 \text { (S.D. 144.6) } \\
118.8 \text { (S.D. 136.6) } \\
128.3 \text { (S.D. 134.7) }\end{array}$ & $\begin{array}{c}4.9^{* *} \text { (S.D. 6.5) } \\
100.1^{*} \text { (S.D. 37.2) } \\
99.8^{* *} \text { (S.D. 21.8) } \\
94.6^{* *} \text { (S.D. 25.5) } \\
124.3 \text { (S.D. 20.5) }\end{array}$ \\
\hline$P$ value & 0.0671 & 0.1707 & $1.2 \times 10^{-8}$ & $9.2 \times 10^{-12}$ & $1.89 \times 10^{-13}$ \\
\hline $\begin{array}{l}\text { Fibroblasts } \\
\begin{array}{l}\text { A }(0.5-3.0) \\
\text { B }(37-63) \\
\text { C }(177-250) \\
\text { D }(420-841) \\
\text { E Control }\end{array}\end{array}$ & $\begin{array}{l}1.1 \text { (S.D. 0.3) } \\
1.8 \text { (S.D. 1.5) } \\
1.9 \text { (S.D. 2.1) } \\
1.7 \text { (S.D. 1.3) } \\
3.1 \text { (S.D. 3.5) }\end{array}$ & $\begin{array}{l}0.4 \text { (S.D. } 0.2 \text { ) } \\
0.7 \text { (S.D. } 0.9 \text { ) } \\
0.7 \text { (S.D. } 0.7 \text { ) } \\
0.5 \text { (S.D. } 0.2 \text { ) } \\
0.5 \text { (S.D. 0.2) }\end{array}$ & $\begin{array}{l}7.988 \text { (S.D. 3.1) } \\
16.5 \text { (S.D. 6.1) } \\
18.1 \text { (S.D. 5.3) } \\
21.3 \text { (S.D. 5.7) } \\
20.6 \text { (S.D. 6.1) }\end{array}$ & $\begin{array}{l}7.7^{\star * *} \text { (S.D. } 3.9 \text { ) } \\
42.3 \text { (S.D. } 6.5 \text { ) } \\
47.4 \text { (S.D. } 8.3 \text { ) } \\
47.8 \text { (S.D. } 9.1 \text { ) } \\
40.4 \text { (S.D. } 8.9 \text { ) }\end{array}$ & $\begin{array}{l}70.8^{* * *} \text { (S.D. 35.5) } \\
302.7 \text { (S.D. 64.3) } \\
335.2 \text { (S.D. 67.4) } \\
349.1 \text { (S.D. 56.4) } \\
385.7 \text { (S.D. 65.1) }\end{array}$ \\
\hline$P$ value & 0.3347 & 0.8155 & $7.52 \times 10^{-6}$ & $9.25 \times 10^{-16}$ & $6.89 \times 10^{-12}$ \\
\hline
\end{tabular}

All data were analysed by the analysis of variance (ANOVA) test. S.D. = standard deviation.

${ }^{\star} P<0.05 ;{ }^{* *} P<0.005 ;{ }^{* * *} P<0.0005$ when compared with control group.

changes of $\mathrm{PGE}_{2}$ concentration in culture medium tested with the smallest particle size $(0.5-3.0 \mu \mathrm{m})$ has a highest level and persisted longer (Table 4). The changes of $\mathrm{PGE}_{2}$ concentration in culture medium corresponded to the changes of cell population when myoblasts were cultured with various sized HA particles. Similar results were observed with fibroblasts.
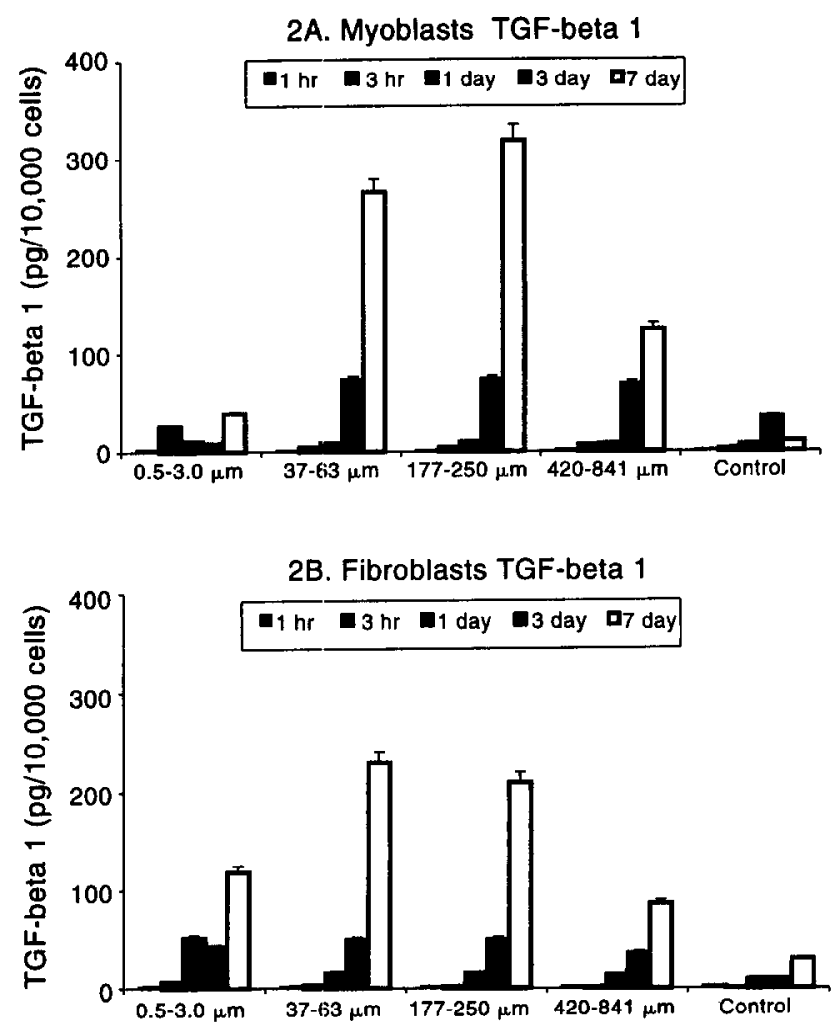

Figure 2 The changes in transforming growth factor- $\beta 1$ (TGF- $\beta 1$ ) titre for myololasts (A) and fibroblasts (B) cultured with various-sized hydroxyapatite (HA) bioceramics (error bar $=$ standard errorl. The TGF- $\beta 1$ titre as a ratio to cell number was significantly affected by the addition of HA $(P<0.005)$. The TGF- $\beta 1$ titre of all particle sizes increased as the culture time increased. The increase in TGF- $\beta 1$ titre was most significant in the groups of medium-sized $(37-63$ and $177-250 \mu \mathrm{m}$ ) particles.
When calculated as a ratio to cell number, the $\mathrm{PGE}_{2}$ titre in all particle sizes also significantly increased compared with the control. The changes in the $\mathrm{PGE}_{2}$ titre were most significant in the groups tested with the smallest particle size (Figure 3). In the myoblasts, the $\mathrm{PGE}_{2}$ titre reached its peaks at $3 \mathrm{~h}$ and 7 days after culture, while in the fibroblasts, the peak $\mathrm{PGE}_{2}$ titre was observed on the first day of culture (Figure 3).

\section{DISCUSSION}

The revolution in biomaterials has promoted recent advancement in orthopaedic surgery. The events at the interface $^{13}$ between an implant material and the adjacent tissue are the direct result of the cellular, chemical, physiological and mechanical reactions evoked by the presence of the biomaterials ${ }^{14}$. In implantation, numerous cell populations and chemical factors are concerned. The in vivo experiments do not allow the examination of a specific cell to the substrate. In order to determine the sequences and the parameters influencing the interactive process, a model of cell culture in the presence of biomaterials is of great interest ${ }^{15}$.

The ability of adult skeletal muscle fibres to regenerate after injury has been well documented since the eighteenth century ${ }^{16}$. Later, numerous investigators ${ }^{17-22}$ reported that adult skeletal muscles did have great capability of regeneration in response to chemical and physical injury. The initial local tissue response to the implant is determined by the effect of normal bone healing in response to the trauma from implantation. However, the skeletal muscles and adjacent fibrous tissue were also exposed to the effect of implantation. The present study was designed to use the skeletal myoblasts and fibroblasts as a simple model for testing the effect of various sized HA particles on soft tissue cells.

Although cell-culture studies cannot directly duplicate the conditions that exist in vivo, the effects of specific types of particles on cellular metabolism can be directly quantified with this technique ${ }^{23}$. There 
Table 4 The changes in prostaglandin $E_{2}\left(P_{G E}\right)$ concentration in culture medium for cells cultured with various-sized synthetic hydroxyapatite (HA) particles at a concentration of $1 \mathrm{mg} \mathrm{m}^{-1}(N=10)$

\begin{tabular}{|c|c|c|c|c|c|}
\hline \multirow[t]{2}{*}{ HA particle size $(\mu \mathrm{m})$} & \multicolumn{5}{|c|}{$\mathrm{PGE}_{2}$ concentration $\left(\mathrm{pg} \mathrm{ml^{-1 }}\right)$} \\
\hline & $1 \mathrm{~h}$ & $3 h$ & 1 day & 3 days & 7 days \\
\hline \multicolumn{6}{|l|}{ Myoblasts } \\
\hline$A(0.5-3.0)$ & $\begin{array}{l}828.1^{\star \star \star} \\
\text { (S.D. 303.6) }\end{array}$ & $\begin{array}{l}801.1^{\star \star \star} \\
\text { (S.D. 204.9) }\end{array}$ & $\begin{array}{l}1681.7^{* * *} \\
\text { (S.D. } 59.9)\end{array}$ & $\begin{array}{l}\text { 1828.7 } \\
\text { (S.D. 838.3) }\end{array}$ & $\begin{array}{l}2056^{* * *} \\
\text { (S.D. 332.5) }\end{array}$ \\
\hline B $(37-63)$ & $\begin{array}{l}115.6^{* * *} \\
\text { (S.D. } 40.9)\end{array}$ & $\begin{array}{l}94.9^{* * *} \\
\text { (S.D. 27.1) }\end{array}$ & $\begin{array}{l}669.9^{* \star \star} \\
(\text { S.D. } 124.7)\end{array}$ & $\begin{array}{l}1458.9^{* * \star} \\
\text { (S.D. } 787.1)\end{array}$ & $\begin{array}{l}1704.1^{* * *} \\
\text { (S.D. } 239.8)\end{array}$ \\
\hline$C(177-250)$ & $91.7^{* * *}$ & $92.9^{* * *}$ & $652.4^{* * *}$ & $1401.7^{\star \star \star}$ & $1665.7^{\star * *}$ \\
\hline D $(420-841)$ & $\begin{array}{l}\text { (S.D. 29.7) } \\
162.6^{* * *}\end{array}$ & $\begin{array}{l}\text { (S.D. } 19.7) \\
74.8^{* * *}\end{array}$ & (S.D. 111.1) & (S.D. 812.3) & (S.D. 251.3) \\
\hline & (S.D. 53.6) & (S.D. 34.3) & (S.D. 179.8) & (S.D. 850.9) & (S.D. 257.2) \\
\hline E Control & $\begin{array}{l}21.4 \\
\text { (S.D. } 4.2)\end{array}$ & $\begin{array}{l}17.9 \\
\text { (S.D. 3.5) }\end{array}$ & $\begin{array}{l}76.1 \\
\text { (S.D. 42.2) }\end{array}$ & $\begin{array}{l}124.4 \\
\text { (S.D. 118.9) }\end{array}$ & $\begin{array}{l}28.7 \\
\text { (S.D. 6.3) }\end{array}$ \\
\hline$P$ value & $6.75 \times 10^{-17}$ & $1.61 \times 10^{-23}$ & $9.49 \times 10^{-31}$ & $8.81 \times 10^{-5}$ & $3.48 \times 10^{-22}$ \\
\hline \multicolumn{6}{|l|}{ Fibroblasts } \\
\hline$A(0.5-3.0)$ & $\begin{array}{l}463.1^{* \star \star} \\
\text { (S.D. 155.9) }\end{array}$ & $\begin{array}{l}351.9^{\star \star \star} \\
\text { (S.D. 68.9) }\end{array}$ & $\begin{array}{l}1574.6^{\star \star \star} \\
\text { (S.D. 60.1) }\end{array}$ & $\begin{array}{l}1376.3^{\star \star \star} \\
\text { (S.D. 133.1) }\end{array}$ & $\begin{array}{l}1707.2^{\star \star \star} \\
\text { (S.D. 56.4) }\end{array}$ \\
\hline B $(37-63)$ & $174.2^{* * *}$ & $77.2^{\star \star \star}$ & $1046.6^{* * *}$ & $987.9^{* * *}$ & $1662.0^{\star \star \star}$ \\
\hline$C(177-250)$ & $171.4^{\star * \star}$ & $74.2^{* * *}$ & $\begin{array}{l}1027.5^{\star \star *} \\
1001\end{array}$ & $\begin{array}{l}\text { (5.D. 127.9) } \\
965.4^{* \star \star}\end{array}$ & $\begin{array}{l}\text { (S.D. } 56.8) \\
1650.2^{* * *}\end{array}$ \\
\hline & (S.D. 59.4) & (S.D. 12.9) & (S.D. 122.5) & (S.D. 199.9) & (S.D. 57.8) \\
\hline$D(420-841)$ & $255.8^{* * *}$ & $58.4^{* * *}$ & $899.9^{* * *}$ & $672.3^{* * *}$ & $1176.2^{\star * *}$ \\
\hline E Control & $\begin{array}{l}\text { (S.D. 109.3) } \\
44.9\end{array}$ & $\begin{array}{l}\text { (S.D. 13.6) } \\
19.9\end{array}$ & $\begin{array}{l}\text { (S.D. 321.4) } \\
451.1\end{array}$ & $\begin{array}{l}\text { (S.D. 173.4) } \\
38.8\end{array}$ & (S.D. 36.2) \\
\hline E Comtror & (S.D. 9.5) & (S.D. 3.8) & (S.D. 359.5) & (S.D. 7.9) & (S.D. 11.2) \\
\hline$P$ value & $9.85 \times 10^{12}$ & $1.9 \times 10^{26}$ & $3.92 \times 10^{12}$ & $7.59 \times 10^{-26}$ & $1.01 \times 10^{-25}$ \\
\hline
\end{tabular}

All data were analysed by the analysis of variance (ANOVA) test. S.D. = standard deviation

${ }^{*} P<0.05 ;{ }^{* *} P<0.005 ;{ }^{* * *} P<0.0005$ when compared with control group.

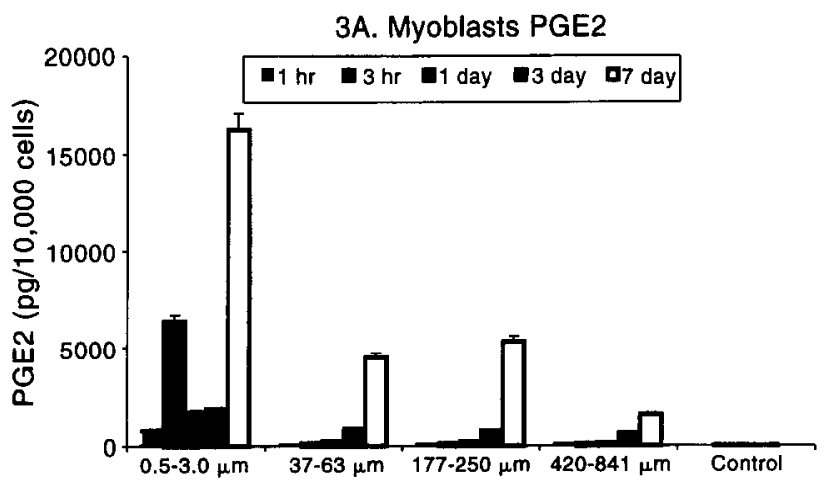

3B. Fibroblasts PGE2

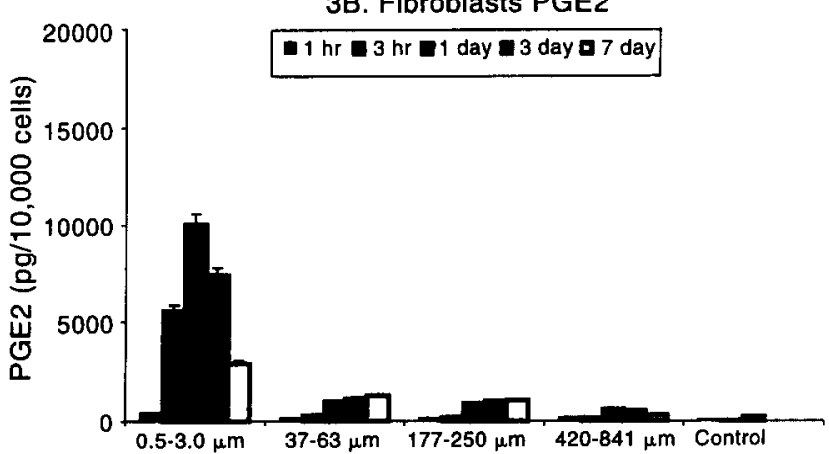

Figure 3 The changes in prostaglandin $E_{2}\left(P G E_{2}\right)$ titre when myoblasts (A) and fibroblasts (B) were cultured with various-sized hydroxyapatite (HA) bioceramics (error bar = standard error). When calculated as a ratio to cell number, the $\mathrm{PGE}_{2}$ titre in all particle sizes increased significantly compared with that of the control $(P<0.005)$. The changes in the $P G E_{2}$ titre were most significant in the group tests with the smallest HA particle size. In the myoblasts, the $\mathrm{PGE}_{2}$ titre reached its peaks at $3 \mathrm{~h}$ and 7 days after culture. while in the fibroblasts, the peak $P G_{2}$ titre was observed on the first day of culture. are several advantages of working with primary cell populations. Because these cells are not transformed, any observed response can be attributed to the phenotype of the cells and not as a possible byproduct of the transforming process ${ }^{24}$.

A decrease in cell number after exposure to the test material can be used as a marker for toxicity ${ }^{25}$. It was previously suggested that toxicity due to direct contact of particles with cells only occurs with particles smaller than about $5 \mu \mathrm{m}$ in diameter ${ }^{26}$. In this study, adding HA particles into cell culture is found to significantly affect the cell count. When myoblasts and fibroblasts were cultured with hydroxyapatite particles, the cell populations of all experimental groups were significantly decreased. The cell population of the smallest sized hydroxyapatite has the fewest cell populations (Table 1). This is inconsistent with findings of Evans and Clarke-Smith ${ }^{26}$. The reduction in growth rate of the cells seen in this experiment could be due to an increase in the death rate of the cells or to a decrease in their mitotic rate.

It was reported that fine particles of hydroxyapatite, normally a very non-toxic material, could cause cell damage in vitro ${ }^{27}$. This toxicity depended on direct contact between cells and particles. The toxicity was associated with membrane damage ${ }^{26}$. There are statistically significant changes in the surface area of the cells after culture with HA particles. These differences were always statistically significant between the control group and various experimental groups (Table 2). This suggested that there were changes in the cell membrane after coculture with HA particles. Later, Evans ${ }^{10}$ showed that the mechanism of the in vitro cell damage depends on a direct interaction between cells and particles and is largely independent of the chemical 
nature of the particle. The invocation of a mechanism involving direct contact does not exclude toxicity due to other mechanism, such as leaching of toxic ions. However, the test material may have a low level of toxicity which, although not sufficient to kill cells, may inhibit normal cell function ${ }^{25}$. The effects of HA on the synthesis and secretion of specific proteins were also evaluated in this study.

The transforming growth factor- $\beta 1$ has been shown to have stimulatory effects on cells ${ }^{28,29}$. In this study, TGF- $\beta 1$ concentrations in culture medium were all significantly decreased by the addition of HA particles. The changes in TGF- $\beta 1$ concentration in the medium with larger sized HA particles (i.e. 37-63, 177-250 and $420-841 \mu \mathrm{m}$ ) were quite similar and close to that of the control medium. The decrease in TGF- $\beta 1$ concentration in the culture medium was most significant in the groups with the smallest particles (i.e. 0.5-3.0 $\mu$ m HA) (Table 3). When calculated as a ratio to the cell number, the increase in the TGF- $\beta 1$ titre was most significant in the groups of medium-sized (i.e. 37-63 and $177-250 \mu \mathrm{m}$ ) particles (Figure 2). This may suggest that the medium-sized $\mathrm{HA}$ is more compatible than that of small particles, as the autoinductive processes can amplify and extend the activity of TGF- $\beta 1^{29}$.

For a given mass of bone cement, smaller particles (less than $20 \mu \mathrm{m}$ ) resulted in more inflammation than large particles $(50-350 \mu \mathrm{m})^{30}$. Irregularly shaped particles produced a greater response than spherical particles. Large particles induced a more intense rise in the white blood-cell count and in the production of prostaglandin $\mathrm{E}_{2}{ }^{30}$. In this study, the $\mathrm{PGE}_{2}$ concentrations in the experimental medium were always significantly higher than that of the control medium. The $\mathrm{PGE}_{2}$ concentration in the control medium increased from day 1 to day 3 , then rapidly decreased to 7 days culture (Table 4). When cells were cultured with $\mathrm{HA}$ particles, the $\mathrm{PGE}_{2}$ concentration reached its peak gradually to day 7 . If we calculated this as a ratio to cell number, the $\mathrm{PGE}_{2}$ titre in all particle sizes also significantly increased compared with the control. The changes in the $\mathrm{PGE}_{2}$ titre were most significant in the groups tested with the smallest particle size (Figure 3).

Prostaglandin $E_{2}$ is a known regulator of protein turnover in skeletal muscle ${ }^{31}$. Prostaglandin $E_{2}$ stimulates muscle protein degradation ${ }^{32,33}$. In this study, the changes in $\mathrm{PGE}_{2}$ concentration in the culture medium were closely related to the changes in cell population when myoblasts were cultured with the various sized $\mathrm{HA}$ particles. The inhibitory effects of the HA particles on the cell culture were possibly mediated by the increased synthesis of $\mathrm{PGE}_{2}{ }^{34}$. It is reported that the ability of various cytokines (including interleukin-1, tumour necrotic factor and transforming growth factor- $\alpha$ ) to stimulate bone resorption is mediated by increased $\mathrm{PGE}_{2}$ synthesis and production of these cytokines is influenced by prostaglandins ${ }^{34}$.

The HA supplied for clinical use is larger than the largest used in this experiment. The results on the effect of various sized HA particles on myoblasts do not mean that the same result will occur in the block form. It does manifest the in vivo effect of the degradation product of HA on the adjacent ingrowing myoblasts. They suggest that caution should be exercised before considering the use of HA products which could easily break down into a fine powder, however well tolerated the bulk form is. In this work, only the biocompatibility of various sized HA particles to the myoblasts and fibroblasts was elucidated. Further studies on the relationships of various sized HA particles to leucocytes are now in progress.

\section{ACKNOWLEDGEMENTS}

The authors sincerely thank the National Science Council (ROC) for their financial support of this research.

\section{REFERENCES}

1. Jarcho, M., Calcium phosphates as ceramics as hard tissue prosthetics. Clin. Orthop., 1981, 157, 259-278.

2. deGroot, K., Bioceramics consisting of calcium phosphate salts. Biomaterials, 1980, 1, 47-50.

3. Cohen, J., Assay of foreign body reaction. J. Bone Joint Surg., 1959, 41A, 152-166.

4. Hupp, J. R. and McKenna, S. J., Use of porous hydroxy apatite blocks for augmentation of atrophic mandibles. J. Oral Maxillofac. Surg., 1988, 46, 533-545.

5. Spector, M., Ahortkroff, S., Sledge, C. B. and Thornhill, T.S., Advances in our understanding of the implantbone interface: factors affecting formation and degeneration. Instructional Course Lecture XI, ed. H. S. Tullos. American Academy of Orthopedic Surgeons, Park Ridge, IL, 1991, pp. 101-113.

6. Amstutz, H. C., Campbell, P., Kossovsky, N. and Clarke, I.C., Mechanism and clinical significance of wear debris-induced osteolysis. Clin. Orthop., 1992, 276, 718.

7. Galante, J. P., Lemons, J., Spector, M., Wilson, P.D. and Wright, T.M., The biologic effects of implants. J. Orthop. Res., 1991, 9, 760-775.

8. Williams, D. F., Toxicity of ceramics. In The Fundamental Aspects of Biocompatibility, ed. D. F. Williams. CRC Prcss, Boca Raton, 1981, pp. 81-94.

9. Whillert, H.G. and Semlitch, M., Reactions of the articular capsule to wear products of artificial prosthesis. J. Biomed. Mater. Res., 1977, 11, 157-164.

10. Evans, E. J., Cell damage in vitro following direct contact with fine particles of titanium, titanium alloy and cobalt-chrome-molybdenum alloy. Biomaterials 1994, 15, 713-717.

11. Cohen, M.C. and Cohen, S., Cytokine function: a study in biologic diversity. Am. J. Clin. Pathol., 1996, 105, 589-598.

12. Bischoff, R., Enzymatic liberation of myogenic cells from adult rat muscle. Anat. Rec., 1974, 180, 645-662.

13. Andrade, J.D., Interfacial phenomena and biomaterials. Med. Instrum., 1973, 7, 110-120.

14. Clark, A.E., Hench, L.L. and Paschall, H. A., The influence of surface chemistry on implant interface histology: a theoretical basis for implant material selection. J. Biomed. Mater. Res., 1976, 10, 161-174.

15. Gregoire, M., Orly, I. and Menanteau, J., The influence of calcium phosphate biomaterials on human bone cell activities. An in vitro approach. J. Biomed. Mater. Res., 1990, 24, 165-177.

16. Grounds, M.D., Towards understanding skeletal muscle regeneration. Pathol. Res. Pract., 1991, 187, 1-22.

17. Baker, J.H. and Poindextor, C. E., Muscle regeneration following segmental necrosis in tenotomized muscle fibers. Muscle and Nerve, 1991, 14, 348-367.

18. Basson, M.D. and Carlson, B. M., Myotoxicity of single and repeated injections of mapivacaine (carbocaine) in the rat. Anesth. Analg. 1980, 59, 275-282.

19. Giddings, C. J., Neaves, W. B. and Gonyea, W. J., Muscle 
fiber necrosis and regeneration induced by prolonged weight-lifting exercise in the cat. Anat. Rec., 1985, 211, 133-141.

20. Hall-Craggs, E.C.B., Ischemic muscle as a model of regeneration. Exp. Ncurol., 1978, 60, 393-399.

21. Jennische, E., Rapid regeneration in post-ischaemic skeletal muscle with undisturbed micro-circulation. Acta. Physiol. Scand., 1986, 128, 409-414.

22. Perth, D. A., Baker, W.C. and Kirkaldy-Willis, W.H., Muscle regeneration in experimental animals and in man: the cycle of tissue change that follows trauma in the injured limb syndrome. I. Bone Joint Surg., 1966, 48B, 153-169.

23. Maloney, W. J. and Smith, R. L., Periprosthetic osteolysis in total hip arthroplasty: the role of particulate wear debris. J. Bone Joint Surg., 1995, 77A, 1448-1461.

24. Ballock, R.T. and Roherts, A. B., In Growth factors: $a$ practical approach, ed. I. McKay and I. Leigh. Oxford University Press, Oxford, 1993, p. 95.

25. Cheung, H. A. and Haak, M. H., Growth of osteoblasts on porous calcium phosphate ceramic: an in vitro model for biocompatibility study. Biomaterials, 1989, 10, 6367.

26. Evans, E. J. and Clarke-Smith, E.M.H., Studies on the mechanism of cell damage by finely ground hydroxyapatite particles in vitro. Clin. Mater., 1991, 7, 241-245.

27. Evans, E. J., Toxicity of hydroxyapatite in vitro: the effect of particle size. Biomaterials, 1991, 12, 574-576.
28. Sporn, M.B., Roberts, A. B., Wakefield, L. M. and de Crombrugghe, B., Some recent advances in the chemistry and biology of transforming growth factor-beta. J. Cell Biol., 1987, 105, 1039-1045.

29. Sporn, M. B. and Robert. A.B., Transforming growth factor-beta. Multiple actions and potential clinical applications. J. Am. Med. Assoc., 1989, 262, 938-941.

30. Gelb, H., Schumacher, H. R., Cuckler, J. and Baker, D.G., In vivo inflammatory response to polymethylmethacrylate particulate debris: effect of size, morphology, and surface area. J. Orthop. Res., 1994, 12, 83-92.

31. Vandenburg, H. H., Hatfaludy, S., Sohar, I. and Shansky, J., Stretch-induced prostaglandins and protein turnover in cultured skeletal muscle. Am. J. Physiol., 1990, 259 (Cell Physiol. 28), C232-C240.

32. Rodemann, H. P. and Goldherg, A. T.., Arachidonic acid, prostaglandin $E_{2}$ and $F_{2}$ influence rates of protein turnover in skeletal and cardiac muscle. J. Biol. Chem., 1982, 257, 1632-1638.

33. Turinsky, J., Phospholipids, prostaglandin $E_{2}$, and proteolysis in derived muscle. Am. J. Physiol., 1986, 251 (Cell Integrative Comp. Physiol. 20), R165-R173.

34. Ibbotson, K. J., Twardzic, D. R., D'Souza, S.M., Hargreaves, W.A., Todaro, G.K. and Mundy, G. R., Stimulation of bone resorption in vitro by systemic transforming growth factor-alpha. Science, 1985, 228, 1007. 